\title{
Kockázatalapú praediabetesszúrés egy vidéki családorvosi praxisban - orális glükóztolerancia-teszt vagy glikált hemoglobin?
}

\author{
Galvács Henrietta - Szabó János dr. - Balogh Zoltán dr. \\ Nemzeti Népegészségügyi Központ, Budapest
}

\begin{abstract}
Bevezetés: A diabetes mellitus prevalenciájának növekedése világviszonylatban is aggasztó tendenciát mutat. Egy erős, jól múködő alapellátás a primer, illetve a szekunder prevencióra fókuszál. Magyarországon kevés idő jut a megelőző munkára, ennek következtében a cukorbetegség, annak kórmegelőző állapotai nem a megfelelő időben kerülnek felismerésre.

Célkitüzés: Az első körben felmérni egy halmozottan hátrányos helyzetü település 18-75 éves korosztályában a diabetes mellitus kialakulásának kockázatát, majd a fokozott, illetve magas rizikócsoportba tartozóknál laborvizsgálati módszerekkel az esetleges szénhidrátanyagcsere-zavarok kiszürése.

Módszer: A diabeteskockázat felmérése FINDRISC-kérdőív segítségével, a szénhidrátanyagcsere-állapot meghatározása pedig a fokozott, illetve magas rizikócsoportba tartozó pácienseknél orális glükóztolerancia-teszt, valamint glikálthemoglobin-vizsgálat elrendelésével történt.

Eredmények: A 406 fős mintában 129 fö $(31,77 \%)$ esetében fokozott, illetve magas diabeteskockázat igazolódott. A rizikó emelkedése az életkor $(p<0,001)$ és a testtömegindex $(p<0,001)$ vonatkozásában szignifikáns összefüggést mutatott. Orális glükóztolerancia-teszttel 28,3\%-ban praediabetes került felismerésre, 9,43\%-ban pedig korábban nem diagnosztizált diabetes mellitus. Glikált hemoglobin alkalmazásával a praediabetes előfordulási gyakorisága $50,94 \%$, a diabetes mellitusé $11,32 \%$ volt. A praediabetes, illetve diabetes mellitus legerősebb prediktora az életkor $(\mathrm{p}=0,047)$ volt. A leggyengébb korreláció a dohányzás $(\mathrm{p}=0,635)$, illetve a fizikai aktivitás $(\mathrm{p}=0,975)$ kapcsán igazolódott. A metabolikus szindróma fennállása átlagosan $0,2 \%$-kal növelte meg a glikálthemoglobin-értéket a vizsgált pácienseknél.

Köpetkeztetések: A kapott eredmények rávilágítottak a prevenciós munka fontosságára. A cukorbetegség jelentôs mortalitási és egészségkárosító kockázata miatt a megelőzés és a korai felismerés kiemelt feladata az alapellátásnak. Az orális glükóztolerancia-teszt mellett a glikálthemoglobin-meghatározás is javasolt, figyelembe véve annak diagnosztikai korlátait. A glikálthemoglobin-eredmények értékelésekor célszerú figyelembe venni, hogy detektálható-e metabolikus szindróma a páciensnél.
\end{abstract}

Orv Hetil. 2019; 160(50): 1976-1983.

Kulcsszavak: praediabetes, glikált hemoglobin, orális glükóztolerancia-teszt, alapellátás, prevenció

\section{Risk-based prediabetes screening in a rural general practice - oral glucose tolerance test or glycated hemoglobin?}

Introduction and aim: The aim of this study was to implement a two-stage diabetes screening programme in a severely disadvantaged municipality. In the first stage, diabetes risk assessment was carried out in the 18 to 75 age group, followed by screening of the high risk population for potential carbohydrate metabolism disorders using laboratory tests.

Method: Stage 1: assessment of diabetes risk with the FINDRISC questionnaire; Stage 2: identification of carbohydrate metabolism status by oral glucose tolerance test and glycated haemoglobin test in patients with elevated or high risk of diabetes.

Results: 406 individuals completed the FINDRISC questionnaire. Elevated or high risk for diabetes was confirmed in 129 individuals $(31.77 \%)$. There was significant correlation between increased risk and age $(\mathrm{p}<0.001)$ and between increased risk and body mass index $(\mathrm{p}<0.001)$. Based on the oral glucose tolerance test, $28.3 \%$ and $9.43 \%$ of the pa- 
tients were diagnosed with pre-diabetes and diabetes mellitus, respectively. According to the glycated haemoglobin test, the incidences of prediabetes and diabetes were $50.94 \%$ and $11.32 \%$, respectively. The strongest predictors of prediabetes/diabetes mellitus was the age $(\mathrm{p}=0.047)$. The correlation between prediabetes/diabetes mellitus and smoking $(\mathrm{p}=0.635)$ and physical activity $(\mathrm{p}=0.975)$ was the weakest. The results showed that the glycated hemoglobin value increased by mean $0.2 \%$ by metabolic syndromes patients.

Conclusions: Our results highlight the necessity for improving preventative care. Based on the risks of significant mortality and disability due to diabetes, prevention and early diagnosis must be prioritised in primary care. In addition to the oral glucose tolerance test, measurement of glycated haemoglobin is also indicated, while keeping in mind the limitations of its diagnostic value. Evaluating for glycated hemoglobin results, it is also worth looking for the presence of metabolic syndrome.

Keywords: prediabetes, glycated hemoglobin, oral glucose tolerance test, primary care, prevention

Galvács H, Szabó J, Balogh Z. [Risk-based prediabetes screening in a rural general practice - oral glucose tolerance test or glycated hemoglobin?]. Orv Hetil. 2019; 160(50): 1976-1983.

(Beérkezett: 2019. július 4.; elfogadva: 2019. augusztus 5.)

\begin{abstract}
Rövidítések
$\mathrm{ADA}=($ American Diabetes Association $)$ Amerikai Diabetes Társaság; $\mathrm{BMI}=($ body mass index $)$ testtömegindex; $\mathrm{CI}=$ (confidence interval) megbízhatósági tartomány; FINDRISC $=$ Finnish Diabetes Risk Score $;$ FPG $=$ (fasting plasma glucose $)$ éhomi vércukorszint; $\mathrm{HbA}_{\mathrm{lc}}=$ hemoglobin-A-lc; $\mathrm{HDL}=$ (high-density lipoprotein) magas sűrűségű liporotein; HPLC = (high-performance liquid chromatography) nagy teljesítményü folyadékkromatográfia; IDF = International Diabetes Federation (Nemzetközi Diabetes Szövetség); IFG = (impaired fasting glucose) emelkedett éhomi vércukorszint; IGT = (impaired glucose tolerance) csökkent glükóztolerancia; $\mathrm{MDT}=$ Magyar Diabetes Társaság; OGTT = orális glükóztoleranciateszt; $\mathrm{SD}=$ (standard deviation) szórás; T2DM = (type 2 diabetes mellitus) 2 -es típusú cukorbetegség; WHO $=$ (World Health Organization) Egészségügyi Világszervezet
\end{abstract}

A 2-es típusú cukorbetegség (T2DM) prevalenciája folyamatosan emelkedik, a Nemzetközi Diabetes Szövetség (IDF) kutatási eredményei alapján 2045-re világszerte várhatóan a $10 \%$-ot is elérheti a cukorbetegek aránya. A praediabetesre vonatkoztatva 2017-ben a csökkent glükóztolerancia (IGT) előfordulási gyakorisága világviszonylatban átlagosan $7,3 \%$ volt ( 352,1 millió ember), ez a szám 2045-re 8,3\%-ra (531,6 millió fó) emelkedhet [1]. Ez nemcsak a betegek várható életkilátása szempontjából jelent problémát, hanem egészséggazdasági szempontból is. A praediabetes a T2DM kórmegelőző állapota, amely a normálvércukorszintet meghaladó, de a diabetes mellitus diagnosztikai kritériumait el nem érő plazmaglükózértékek esetén mondható ki. A T2DM kezdetben meglehetősen tünetszegény, ami nehezíti a korai felismerést. Lényeges, hogy a praediabetes már a cukorbetegség diagnosztizálása előtt kb. 5-15 évvel is kialakulhat, ebben az időszakban pedig már a célszervi károsodások - föként a macrovascularis szövődmények - is megjelenhetnek. Emellett a kedvezőtlen szénhidrátanyagcsere-status a daganatos betegségek kialakulásának is kedvez [2-4]. A praediabetes kapcsán két entitást különböztethetünk meg: az IFG-t (impaired fasting glucose - emelkedett éhomi vércukorszint) és az IGT-t (impaired glucose tolerance - csökkent glükóztolerancia); ez utóbbi csak orális glükóztolerancia-teszttel (OGTT) állapítható meg. Mindkettő elófordulhat izolált, illetve együttes formában is. A diagnosztikai kritériumrendszert illetôen az Egészségügyi Világszervezet (WHO), illetve az Amerikai Diabetes Társaság (ADA) is önálló ajánlást fogalmazott meg. Az ADA ajánlása egyébként szigorúbb, az éhomi vércukorszint esetében már $5,6 \mathrm{mmol} / 1$ feletti vércukorértéknél IFG-t véleményez. Hazánkban a WHO kritériumrendszerét alkalmazzuk, amelyet a Magyar Diabetes Társaság (MDT) is adaptált irányelvében. A hazai előfordulási gyakoriságra vonatkozó néhány kutatási eredmény: Jermendy és mtsai 2010-2011ben 20 és 69 év közötti felnőtteket vizsgáltak országos reprezentatív keresztmetszeti vizsgálat keretében. A kutatásban diabetes mellitus és IFG vonatkozásában végeztek elemzéseket 1803 fó részvételével. A manifeszt diabetes előfordulási aránya $8,65 \%$ volt (súlyozott elöfordulási aránya 7,47\%), míg az IFG prevalenciája súlyozott korrekció után 4,39\% [5]. Szintén 2010-2011-ben Winkler és mtsai alapellátásban dolgozó háziorvosok bevonásával kockázatalapú (FINDRISC-kérdőív) diabetesszürést végeztek. 22846 páciens esetében történt terheléses vércukorszint-vizsgálat, és az elvégzett vizsgálatok alapján a páciensek 46,53\%-ánál igazolódott manifeszt diabetes mellitus, illetve annak valamilyen kórmegelőző állapota (IFG 14,1\%, IGT 24,8\%, manifeszt diabetes 7,6\%) [6,7]. Gyermekeknél Barkay és Madácsy végzett diabetesszúrést 2008 áprilisa és 2009 márciusa között hazánkban. A T2DM kockázatfelmérésére az ADA ajánlása alapján összeállított kérdőív segítségével került sor. A 660 serdülő közül a kérdőív alapján 285 gyermek esetében fokozott diabeteskockázat volt megállapítható. Ezen serdülők közül 16 fö $(5,61 \%)$ esetében a glükózintolerancia valamilyen formáját lehetett igazolni. 
4 gyermek esetében (1,40\%) IFG, 5 gyermek esetében $(1,75 \%)$ IFG + IGT, 6 gyermek esetében $(2,11 \%)$ IGT és 1 gyermeknél (0,35\%) T2DM igazolódott [8].

A diabetes szúrésére vonatkozóan az 51/1997. (XII. 18.) népjóléti minisztériumi rendelet, a kötelezö egészségbiztositás keretében igénybe vehető betegségek megelozését és korai felismerését szolgáló egészségügyi szolgáltatásokról és a szúrốvizsgálatok igazolásáról szóló jogszabály az irányadó a háziorvosi szolgálatok szűrővizsgálati tevékenységére vonatkozóan. Mindezek alapján 21 éves kortól a T2DM szempontjából nagy kockázatú egyéneknél (elhízás, a diabetes mellitus családi halmozódása, a kórelőzményben gestatiós diabetes) OGTT elvégzését (éhomi és 120 perces értékek értékelése) vagy ennek kivitelezhetetlensége esetén éhomi és postprandialis vércukorszint meghatározását javasolja a cardiovascularis rizikóbesorolástól függően két-, illetve ötévente [9].

A nemzetközi szakmai ajánlások is jó néhány éve javasolják a $\mathrm{HbA}_{\mathrm{lc}}$ alkalmazását szürővizsgálatként, bár a többféle metodikai és diagnosztikus határértékek még vitatottak [10]. Néhány esetben azonban nem alkalmazható, ilyen kórállapotok például: akut pancreasbetegség, gyógyszer indukálta hyperglykaemia, haemoglobinopathiák, súlyos anaemia, májelégtelenség, dialízis és $\mathrm{HIV}$-fertőzés. Bizonyos állapotokban a $\mathrm{HbA}_{\mathrm{lc}}$ emelkedése is megfigyelhető, például: hypertriglyceridaemiánál (HPLC), hyperbilirubinaemiánál (HPLC), aszpirinszedés mellett, uraemiában, aplasztikus anaemiában, szplenektomizált betegeknél, az életkor emelkedésével (10 évente $0,1 \%$ ) vagy a kelet-ázsiai, illetve az afrikai populációban - ezeket figyelembe kell venni az eredmények értékelésekor [11]. Mivel mindkét módszernek (OGTT, illetve $\mathrm{HbA}_{\mathrm{lc}}$ ) vannak elönyei, illetve korlátai, célszerü az FPG, illetve az OGTT mellett $\mathrm{HbA}_{1 \mathrm{c}}$-vizsgálatot is végezni a diagnosztikai pontosság érdekében [12].

Szürővizsgálatként napjainkban az úgynevezett kockázatalapú, kétlépcsős módszer a leginkább elfogadott: ennek értelmében az első lépcsóben kérdőív segítségével rizikóazonosítás történik, a második lépcsőben pedig a fokozott, illetve magas rizikójú pácienseknél vércukorszint-meghatározás indokolt. Amennyiben az OGTT negatív eredményú, úgy ismétlése háromévente javasolt. A rizikókérdőívek közül validitása miatt a FINDRISC használata terjedt el a legtöbb országban (így hazánkban is ) $[13,14]$. A rizikóbecslés, illetve a laboratóriumi szürővizsgálat segítségével a kórmegelőző állapotok sikerrel azonosíthatók, amivel a T2DM előfordulási gyakorisága is csökkenthető [15].

\section{Módszer}

Keresztmetszeti, deskriptív kutatásunkat a Borsod-Abaúj-Zemplén, Heves, Nógrád Megyei Regionális/Intézményi Tudományos Kutatásetikai Bizottsága IG-10299/2018 számon engedélyezte.

A kutatást a Heves megyei Átány község háziorvosi szolgálatánál végeztük, a 2018. május és 2019. január közötti időszakban. A település a halmozottan hátrányos helyzetú régiók egyikének része. A községben, amelynek lélekszáma kb. 1500 fó, típusát tekintve egy vegyes háziorvosi szolgálat múködik. A kutatásba a praxisba bejelentkezett 18-75 éves lakosok kerültek beválasztásra, akiknél korábban még nem diagnosztizáltak szénhidrátanyagcsere-zavart. Kizárásra kerültek a várandósok, illetve a mozgásukban súlyosan korlátozottak (a laborvizsgálatra történő beutazás nehézsége miatt). A kutatást az említett kétlépcsős módszerrel végeztük. Az első körben a diabeteskockázat felmérése történt, majd a fokozott és magas kockázatú egyéneknél a második lépcsőben vénás plazmából OGTT-et, illetve $\mathrm{HbA}_{1 \mathrm{c}}$-vizsgálatot indikáltunk. A diabetesrizikó meghatározásához a FINDRISCkérdőívet alkalmaztuk. Az adatfelvételt az ápoló kollégák végezték, a páciensek rendelőben történő megjelenésekor. A FINDRISC-kérdőív értékelése az alábbi szempontokat követte:

- kevesebb, mint 7 pont: alacsony kockázat;

- 7-11 pont: enyhén fokozott kockázat;

- 12-14 pont: fokozott kockázat;

- 15-20 pont: magas kockázat;

- több, mint 20 pont: igen magas kockázat.

Az OGTT kivitelezését a területileg illetékes járóbeteg-szakellátó intézményben végezték el, a szakmai ajánlásoknak megfelelóen éhgyomorra, majd 75 gramm glükóz elfogyasztása után 120 perccel. A szénhidrátanyagcsere-status meghatározása a WHO ajánlásának megfelelő labordiagnosztikai kritériumrendszer szerint történt. Ennek alapján IFG állapítható meg, ha az éhomi plazma glükózértéke $6,1 \mathrm{mmol} / \mathrm{l}$ vagy nagyobb, de kisebb, mint 7,0 mmol/l. IGT akkor állapítható meg, ha az éhomi vércukorszint $<7,0 \mathrm{mmol} / \mathrm{l}$, és az OGTT 2 órás értéke $\geq 7,8 \mathrm{mmol} / 1$, de $<11,1 \mathrm{mmol} / 1$. Abban az esetben, ha a 2 órás érték megfelel az IGT-nek, és az éhomi vércukorérték 6,1 és 6,9 mmol/1 közé esik, IGT + IFG együttes fennállása állapítható meg. Ha az éhomi vércukor $\leq 6,0 \mathrm{mmol} / 1$, és a terhelés utáni 120 perces vércukorérték 7,8-11,0 mmol/1 közötti, akkor izolált IGT állapítható meg. A $\mathrm{HbA}_{\mathrm{lc}}$ vonatkozásában normálszénhidrátanyagcsere-status véleményezhető 5,6\%-ig, praediabetes 5,7 és $6,4 \%$ között és diabetes mellitus 6,5\%-os $\mathrm{HbA}_{\mathrm{lc}}$-értéktől [16]. Az antropometriai adatok közül BMI-számítást, haskörfogatot, testmagasságot mértünk rendelői körülmények között. A BMI-számításkor a WHO szerinti kategorizálást alkalmaztuk (1. táblázat) [17].

A laboreredménnyel rendelkező pácienseknél megvizsgáltuk az esetleges metabolikus szindróma fennállását is. Az IDF kritériumrendszerét alkalmaztuk, amely szerint metabolikus szindróma véleményezhető, ha:

- a centrális obesitas (definíció szerint $\geq 94 \mathrm{~cm}$-es derékkörfogat europid férfiak és $\geq 80 \mathrm{~cm}$ europid nók esetében) mellett a következő négy faktor közül bármelyik kettő jelenléte igazolható; mindezek:

- a trigliceridkoncentráció: >1,7 mmol/1, vagy emiatt gyógyszeres kezelésben részesül; 
A testtömegindex meghatározása az Egészségügyi Világszervezet kritériumrendszere alapján

\begin{tabular}{ll}
\hline Testtömegindex-eredmény & Tápláltsági állapot \\
\hline $16,00 \mathrm{~kg} / \mathrm{m}^{2}$ alatt & Súlyos soványság \\
$16,00-16,99 \mathrm{~kg} / \mathrm{m}^{2}$ & Mérsékelt soványság \\
$17,00-18,49 \mathrm{~kg} / \mathrm{m}^{2}$ & Enyhe soványság \\
$18,5-24,99 \mathrm{~kg} / \mathrm{m}^{2}$ & Normáltestsúly \\
$25,00-29,99 \mathrm{~kg} / \mathrm{m}^{2}$ & Túlsúlyos \\
$30,00-34,99 \mathrm{~kg} / \mathrm{m}^{2}$ & Elhízott I. stádium \\
$35,00-39,99 \mathrm{~kg} / \mathrm{m}^{2}$ & Elhízott II. stádium \\
$40,00 \mathrm{~kg} / \mathrm{m}^{2} \mathrm{vagy}$ a felett & Elhízott III. stádium \\
\hline
\end{tabular}

- alacsony HDL-koleszterin-koncentráció: < 1,03 mmol/1 a férfiak és <1,29 mmol/1 a nők esetében, vagy emiatt gyógyszeres kezelésben részesül;

- emelkedett vérnyomás: a szisztolés érték $\geq 130$ Hgmm vagy a diasztolés érték $\geq 85 \mathrm{Hgmm}$ vagy korábban diagnosztizált hypertonia, vagy emiatt gyógyszeres kezelésben részesül;

- emelkedett éhomi vércukor-koncentráció: $\quad 25,6$ $\mathrm{mmol} / \mathrm{l}$, vagy korábban diagnosztizált 2 -es típusú diabetes mellitus $[18,19]$.

Célkitűzésünk a hátrányos helyzetû régióban élők körében a szénhidrátanyagcsere-zavarok diagnosztizálása, mindemellett az OGTT és a $\mathrm{HbA}_{\mathrm{lc}}$ alkalmazása közötti prevalenciakülönbség megállapítása. Mivel a hazai szakirodalomban nem találtunk $\mathrm{HbA}_{\mathrm{lc}}-\mathrm{n}$ alapuló diabetesszürési eredményeket, nemzetközi adatokra támaszkodtunk, illetve ezekkel végeztünk összehasonlító számításokat.

\section{Statisztikai módszerek}

A kutatási eredményeket leíró, valamint matematikai statisztikai módszerekkel SPSS 22.0 (IBM Corporation, Chicago, IL, Amerikai Egyesült Államok [USA]), illetve Excel-program (Microsoft Corporation, Redmond, WA, USA) segítségével dolgoztuk fel. A leíró statisztikai módszereknél átlagot, szórást (SD), valamint megbízha-

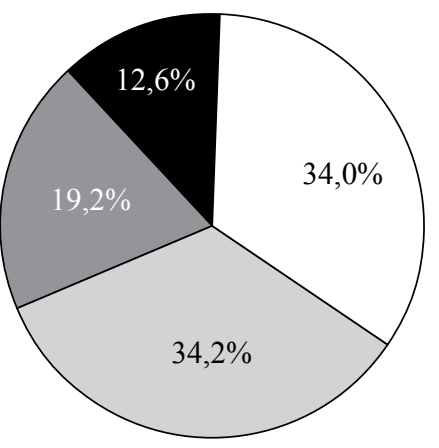

$\begin{array}{llll}\text { Alacsony } & \square \text { Enyhén fokozott } \\ \text { kockázat } & \begin{array}{l}\text { Fockázat } \\ \text { kockott }\end{array} & \text { Magas } \\ \text { kockázat } & \text { kockázat }\end{array}$ \begin{tabular}{l|l} 
1. ábra & $\begin{array}{l}\text { A páciensek diabetesrizikó-besorolása százalékos megoszlásban } \\
(\mathrm{n}=406)\end{array}$
\end{tabular}

tósági tartományokat (CI) számoltunk és tüntettünk fel. Változóink normáleloszlásának hiányában a csoportok közötti összefüggések vizsgálatára nem paraméteres teszteket (Mann-Whitney- és Kruskal-Wallis-teszt), a minőségi változók esetében, valamint a metabolikus szindróma és a $\mathrm{HbA}_{\mathrm{lc}}$ közötti összefüggések vizsgálatára pedig khi-négyzet-próbát, illetve Fisher-féle egzakt teszteket alkalmaztunk. A szignifikanciaszintet 5\%-ban határoztuk meg $(\mathrm{p}<0,05)$.

\section{Eredmények}

Az 1485 fós praxisban 481 fó volt 18 éven aluli. A felnőttek körében 830 fó felelt meg a bevonási kritériumoknak. A szóba jöhető 830 fó 48,91\%-ával (406 páciens) töltöttünk ki FINDRISC-kérdőívet. 146 férfi $(35,96 \%)$, illetve 260 nő $(64,04 \%)$ vett részt a vizsgálatban. Az átlagéletkor 44,59 $\pm 15,43$ SD év (95\% CI 43,02-46,03), míg a kérdőíveknél kapott pontszám átlaga $9,26 \pm 4,55 \mathrm{SD}$ pont $(95 \%$ CI $8,82-9,71)$ volt. A mintában 31,77\% (129 fó) bizonyult fokozott, illetve magas kockázatú egyénnek (1. ábra). A teljes mintában a pácienseink 51,97\%-a (211 fó) rendszeresen dohányzik. Hypertonia miatt a páciensek 17,48\%-a (71 fó) áll gondozás alatt, mindössze $7,63 \%$ (31 fó) nyilatkozott

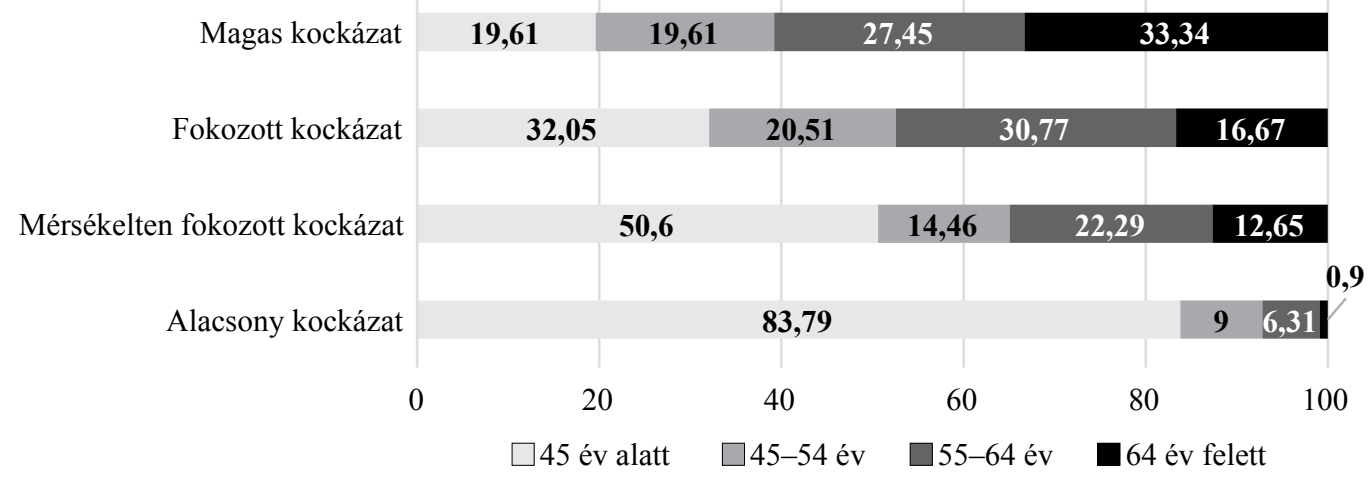




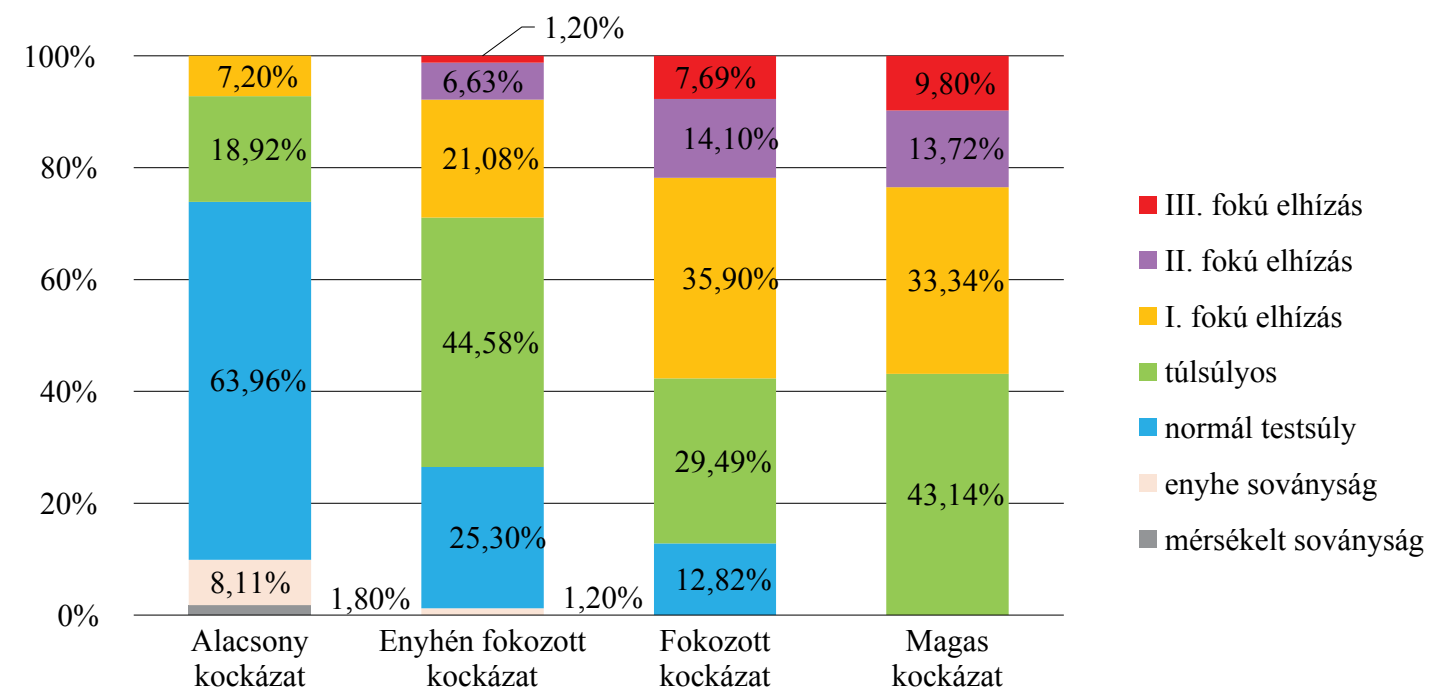

3. ábra

| A testtömegindex és a diabetesrizikó-növekedés kapcsolata százalékos megoszlásban $(\mathrm{n}=406)$

úgy, hogy nem végez legalább napi 30 perces fizikai munkát. Diabetes szempontjából pozitív családi anamnézissel 50,73\% (206 fó) rendelkezett.

A FINDRISC-eredmények alapján a férfiak esetében $56,3 \%$ (107 fó) az alacsony, illetve enyhén fokozott kockázatú, míg 43,7\% (39 fó) a fokozott, illetve magas rizikócsoportba tartozott. Nők esetében az eredmények az alábbiak szerint alakultak: 47\% (170 fo') alacsony, illetve enyhén fokozott kockázatú, míg 53\% (90fö) fokozott, illetve magas rizikójú páciensnek tekinthető. A magasabb életkor jelentôs kockázatnövekedést jelentett a vizsgált populációban, 45 éves kor felett igazoltunk szignifikáns kockázatnövekedést $(\mathrm{p}<0,001)$ (2.ábra).

Mint ismeretes, az elhízás az egyik legerôsebb prediszponáló tényezô a T2DM kialakulása szempontjából. A minta átlag-BMI-értéke $27,39 \pm 5,68 \mathrm{SD} \mathrm{kg} / \mathrm{m}^{2}$ (95\% CI 26,84-27,95). Mindössze 3,2\%-nál (13 fö) igazoltunk mérsékelt, illetve enyhe soványságot. A normálBMI-vel rendelkező páciensek aránya 30,29\% (123fó), a túlsúlyos pácienseké 34,48\% (140fö) volt. A megkérdezettek 32,01\%-a (130 fó) pedig az elhízás különböző súlyosságú kategóriáiba volt sorolható. Míg a mintában az alacsony kockázatú csoportban a páciensek mindössze 26,12\%-a tekinthetó túlsúlyosnak, illetve elhízottnak, addig a fokozott kockázatú egyéneknél ez az arány már 87,18\%. A magas kockázati csoportban már nem volt normáltestsúllyal rendelkező páciens, 100\%-uk különböző mértékü testsúlyfelesleggel rendelkezett (3. ábra). A testsúly, illetve a diabeteskockázat emelkedése között a mintában szignifikáns összefüggést igazoltunk $(\mathrm{p}<0,001)$.

A magas, illetve fokozott kockázatú egyének (129 fó) esetében szóbeli tájékoztatás után laborvizsgálatot indikáltunk, közülük - többszöri próbálkozás után is - 53 fó vett részt a vizsgálatban (41,08\%). 2 fó időközben elhalálozott, 3 fó pedig elköltözött a településrôl. 3 fó egyértelmúen visszautasította a vizsgálatban való részvételt. A többi pácienstől semmilyen visszajelzés nem érkezett a részvétellel kapcsolatban a háziorvosi szolgálatban dolgozók felé. Az igazolt szénhidrátanyagcsere-zavarral rendelkező páciensek átlagéletkora a mintában 57,4 \pm 10,35 SD év $(95 \%$ CI 53,84-60,96) volt. Az elvégzett vérvizsgálatok alapján jelentős különbséget tapasztaltunk a két labordiagnosztikai paraméter alkalmazása között (4. ábra). OGTT-vel 62,26\%-ban (33 fö) normálszénhidrátanyagcsere-statust, 28,3\%-ban (15 fö) a praediabetes valamelyik entitását (IFG: 1,89\%, IGT: 15,09\%, IFG + IGT: $11,32 \%$ ), illetve 9,43\%-ban (5 fo) manifeszt, de korábban fel nem ismert diabetes mellitust igazoltuk. Ezzel szemben $\mathrm{HbA}_{\mathrm{lc}}$ alkalmazásával a normálanyagcsere-statusú páciensek aránya 37,74\% (20f”), a praediabetes előfordulási gyakorisága 50,94\% (27 fó), a diabetes mellitusé pedig 11,32\% (6 fö) volt. Összességében tehát 1,8 -szeres prevalenciakülönbség tapasztalható a két laboratóriumi módszer alkalmazása között, a

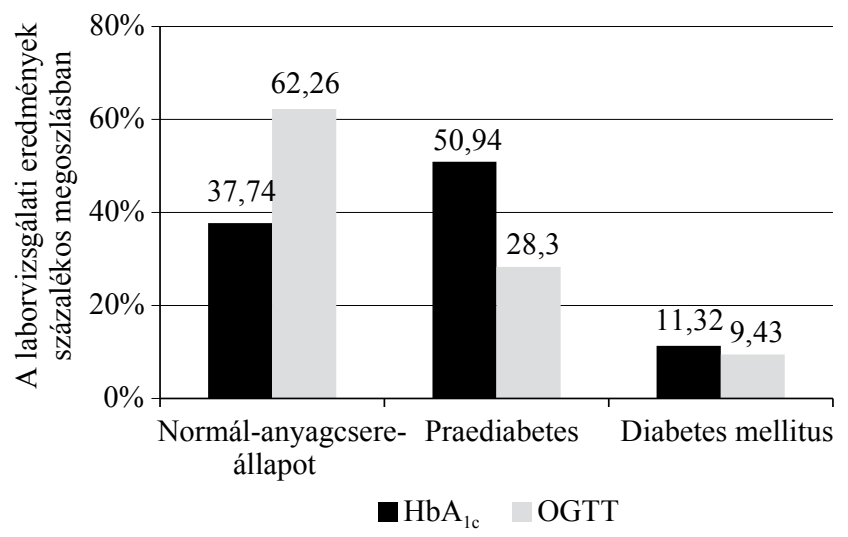

4. ábra Az igazolt szénhidrátanyagcsere-állapotok százalékos megosz-
lásban az orális glükóztolerancia-teszt és a glikált hemoglobin
vonatkozásában $(\mathrm{n}=53)$
$\mathrm{HbA}_{\mathrm{lc}}=$ hemoglobin-A-lc; OGTT = orális glükóztolerancia-
teszt 
2. táblázat |A rizikótényezők és a szénhidrátanyagcsere-zavarok közötti öszszefüggések vizsgálata $(\mathrm{n}=53)$

\begin{tabular}{lll}
\hline Vizsgált rizikótényező & Az alkalmazott statisztikai módszer & p-érték \\
\hline Életkor & Mann-Whitney & 0,047 \\
Családi anamnézis & Khi-négyzet-próba & 0,089 \\
Hypertonia & Khi-négyzet-próba & 0,105 \\
Nem & Khi-négyzet-próba & 0,177 \\
Testtömegindex & Mann-Whitney & 0,458 \\
Haskörfogat & Mann-Whitney & 0,516 \\
Dohányzás & Khi-négyzet-próba & 0,635 \\
Fizikai aktivitás & Khi-négyzet-próba & 0,972 \\
\hline
\end{tabular}

$\mathrm{HbA}_{\mathrm{lc}}$ javára. Amennyiben az FPG-t és a $\mathrm{HbA}_{\mathrm{lc}}$-t tekintjük a két labordiagnosztikai szürőmódszerünknek (mint a legtöbb nemzetközi összehasonlító vizsgálatban), úgy 3,8-szeres a különbség. Itt azokkal a páciensekkel számoltunk, akiknél izolált IFG vagy IFG mellett együttesen IGT is elöfordult $(13,20 \%, 7$ fó).

A pozitív laboreredménnyel rendelkező pácienseknél összefüggés-vizsgálatok történtek arra vonatkozóan, hogy mely ismert rizikótényezők befolyásolták a leginkább a szénhidrátanyagcsere-zavarok kialakulását. A legerősebb prediktornak az életkor $(\mathrm{p}=0,047)$, illetve a pozitív családi anamnézis $(\mathrm{p}=0,089)$ bizonyult, de csak az előbbinél beszélhetünk szignifikáns összefüggésról. A leggyengébb korrelációt a dohányzás $(p=0,635)$, illetve a fizikai aktivitás $(\mathrm{p}=0,975)$ között igazoltuk (2. táblázat).

Az IDF kritériumrendszere alapján a laboratóriumi vizsgálati eredménnyel rendelkező páciensek 69,81\%ánál (37 fó) metabolikus szindróma igazolódott. Itt szintén a nők aránya volt magasabb $(43,4 \%)$. Megállapítást nyert, hogy a praediabeteses betegeknél a metabolikus szindróma előfordulási gyakorisága $(\mathrm{p}<0,05)$ szignifikánsan magasabb, a normál-szénhidrátanyagcserével rendelkező páciensekkel összehasonlítva. Megvizsgáltuk továbbá a normálanyagcsere-statusú, illetve praediabeteses betegeinknél, hogy a metabolikus szindróma fennállása okozhat-e $\mathrm{HbA}_{1 \mathrm{c}}$-emelkedést. Mind a normálanyagcsere-statusú, mind a praediabeteses csoportban

3. táblázat |A glikált hemoglobin átlagértékei a metabolikus szindróma vonatkozásában ( $\mathrm{n}=$ az adott kategóriába tartozó páciensek száma; SD = szórás

\begin{tabular}{llll}
\hline $\begin{array}{l}\text { Szénhidrátanyag- } \\
\text { csere-állapot* }^{*}\end{array}$ & $\begin{array}{l}\text { Metabolikus } \\
\text { szindróma negatív }\end{array}$ & $\begin{array}{l}\text { Metabolikus } \\
\text { szindróma pozitív }\end{array}$ & p-érték \\
\hline Normál & $\begin{array}{l}5,20 \pm 0,22 \% \text { SD } \\
(\mathrm{n}=12 ; 57,89 \%)\end{array}$ & $\begin{array}{l}5,41 \pm 0,13 \% \text { SD } \\
(\mathrm{n}=8 ; 42,11 \%)\end{array}$ & 0,375 \\
\hline Praediabetes & $\begin{array}{l}5,8 \pm 0,08 \% \text { SD } \\
(\mathrm{n}=4 ; 14,82 \%)\end{array}$ & $\begin{array}{l}5,97 \pm 0,25 \% \mathrm{SD} \\
(\mathrm{n}=23 ; 85,18 \%)\end{array}$ & 0,879 \\
\hline
\end{tabular}

*A szénhidrátanyagcsere-állapot meghatározása a $\mathrm{HbA}_{\mathrm{lc}}$-értékek alapján. szignifikánsan ugyan nem ( $\mathrm{p}=0,375$ és $\mathrm{p}=0,879)$, de átlagosan $0,2 \%$-kal magasabb $\mathrm{HbA}_{\mathrm{lc}}$-értékeket kaptunk, ha metabolikus szindróma is fennállt (3. táblázat). Diabetes vonatkozásában nem végeztük el ugyanezt a vizsgálatot, mivel minden cukorbeteg páciens ( 6 fó) egyidejúleg metabolikus szindrómában is szenvedett.

\section{Megbeszélés}

A kutatás eredményei számos problémára rávilágítottak. Az a tény, hogy a vizsgált páciensek 37,73\%-a, illetve 62,26\%-a (laborparamétertől függően) a szénhidrátanyagcsere-zavar valamelyik formájában szenved, rámutat a diabetes mellitus igen jelentős népegészségügyi vonzatára. A hevesi járásban - beleértve az érintett községet is - magas a rossz szociális, illetve anyagi körülmények között élők aránya. Néhány kiemelkedő adat: az Észak-magyarországi régióban élő roma lakosság aránya a Debreceni Egyetem 2010-2013. évi felmérése alapján kb. 24,4\%, akiknek átlagéletkora kb. 10 évvel alacsonyabb a nem roma populációval összehasonlítva [20]. A nyers halálozási arányszám 2016-ban a hevesi járásban 14,8 , az országos viszonylatban 12,9 ezrelék volt. A megye halálozási statisztikáit áttekintve 2016-ban az első helyen a keringési rendszer megbetegedései (768/100 ezer fó), a másodikon pedig a daganatos betegségek (388/100 ezer fó) miatti halálozások álltak, az országos átlagot meghaladóan [21]. A munkanélküliségi ráta a régióban 2019 első negyedévében 4,6 volt [22]. A nyilvántartott álláskeresők száma a hevesi járásban a gazdaságilag aktív népességre vetítve $17 \%$, ami a megyében is a legrosszabbnak tekinthető. A munkaeröpiac minden ötödik tagja regisztrált álláskereső, valamint minden negyedik aktív tagja közfoglalkoztatott, 66\% legfeljebb általános iskolai végzettséggel rendelkezik [23]. Mindezen adatok mellett nem meglepőek a kutatásunk során igazolt eredmények sem, hogy a társadalmi-gazdasági státusz milyen hatással van az egészségi állapotra. A szakirodalommal egyezően mi magunk is igazoltuk, hogy 45 év felett szignifikánsan emelkedik a diabetes kialakulásának kockázata, így ezen korosztálytól kezdve a rendszeres szürés kiemelt fontosságú. Az időben felismerésre kerülő szénhidrátanyagcsere-zavar megfelelő intervencióval akár vissza is fordítható. A szúróvizsgálatot mindenképp rizikóazonosítással, illetve -becsléssel célszerü kezdeni, melyet a törzskarton-megújításoknál érdemes ismételten elvégezni [24]. Mivel az izolált IGT jelentősen nagyobb számban fordult elő, a rizikócsoportba tartozó pácienseknél az OGTT kezdeményezése elengedhetetlen, még akkor is, ha az FPG negatív eredményú. A $\mathrm{HbA}_{\mathrm{lc}}$ alkalmazása igen hasznos és informatív, a nagy kockázatú egyének esetében kifejezetten célszerú elrendelni a szürővizsgálat alkalmával - az FPG, illetve OGTT kiegészítéseként -, természetesen figyelembe véve a módszer diagnosztikus korlátait [25]. Egyes szakirodalmi források egyébként javasolják még a 120 perces érték helyett a 60 perces postprandialis vércukorszint vizsgálatát a ma- 
gas kockázatú egyének esetében [26]. Kutatásunkban azt is megvizsgáltuk, hogy a metabolikus szindróma fennállása okozhat-e $\mathrm{HbA}_{\mathrm{lc}}$-emelkedést. Az eredmények alapján mind a normál szénhidrátanyagcsere, mind a praediabetes állapotában átlagosan $0,2 \%$-kal magasabb $\mathrm{HbA}_{\mathrm{lc}}$-értékek igazolódtak azoknál a pácienseknél, akiknél metabolikus szindróma is detektálható volt. Mindez a napi gyakorlatban is hasznos segítség lehet, mert megállapítható a valós szénhidrátanyagcsere-status olyan kétes esetekben, amelyekben a két labordiagnosztikai módszer alapján nem egyértelmú a páciens szénhidrátanyagcsere-statusa. Az FPG és a $\mathrm{HbA}_{\mathrm{lc}}$ alkalmazását illetően a nemzetközi szakirodalomban fellelhető kutatási eredményekhez képest közel megegyező volt a saját vizsgálatunkban tapasztalt 3,8-szeres prevalenciakülönbség (FPG vs. $\mathrm{HbA}_{\mathrm{lc}}$ ) [27-29]. A vizsgálatban részt vevőkkel kapcsolatban fontos hangsúlyozni, hogy a szénhidrátanyagcsere-zavar mellett minimum egy cardiovascularis rizikótényező is fennáll, ezzel még tovább növelve a korai halálozás, illetve egészségkárosodás kockázatát. Jelentős számú dohányos volt a vizsgálatban részt vevők között $(51,97 \%)$; a WHO 2016. évi adatai alapján Magyarország lakosságának 28,7\%-a dohányzik rendszeresen, kutatásunk eredménye tehát az országos átlagot is jelentősen meghaladja [30]. A túlsúly, illetve elhízás kapcsán eredményeink megegyeztek a 2014-ben végzett Országos Táplálkozás és Tápláltsági Állapot Vizsgálat során rögzített adatokkal [31]. A nők aránya mind a diabetesrizikó tekintetében, mind az igazolt szénhidrátanyagcsere-zavarban szenvedők körében magasabb volt.

A kutatás alatt egyértelmúen bebizonyosodott, hogy az alacsony iskolázottság, a rossz szociális és anyagi körülmények jelentősen befolyásolják a morbiditást, a mortalitást, valamint a prevenciós munka hatékonyságát az alapellátásban. Összegezve tehát, a családorvosi szolgálatnál dolgozóknak, eredményeink fényében, nagyobb hangsúlyt kell helyezniük a primer, illetve szekunder prevencióra. A régióban egyébként is magasabb a daganatos, illetve cardiovascularis megbetegedések miatti halálozás, amihez a diabetes akár jelentősen hozzá is járulhat. Éppen ezért fontos a megelőzés, illetve a korai felismerés. Amennyiben már a kórmegelőző állapotokban sikerül felismernünk a szénhidrátanyagcsere-zavarokat, úgy ez a folyamat a páciens megfelelő együttmúködése mellett akár vissza is fordítható, vagy legalább késleltethető a diabetes, illetve szövődményeinek a kialakulása. Ennek sikerességében pedig az alapellátásnak van a legmeghatározóbb szerepe.

Anyagi támogatás: A szerzők anyagi támogatásban nem részesültek.

Szerzői munkamegosztás: G. H.: A kutatás megtervezése, lebonyolítása, az eredmények értékelése, feldolgozása, a kézirat megírása. Sz. J.: A kutatás megtervezése, a kutatáshoz szükséges helyszín, illetve beteganyag biztosítása, a kutatás orvosszakmai szempontból történő támogatása. B. Z.: A kutatás megtervezésében való közremúködés, az eredmények értékelése, a kézirat megírásának szakmai támogatása. A cikk végleges változatát mindhárom szerző elolvasta és jóváhagyta.

Érdekeltségek: A szerzőknek nincsenek érdekeltségeik.

\section{Köszönetnyilvánítás}

A szerzők szeretnének köszönetet mondani Átány község Önkormányzatának - mint a háziorvosi szolgálat fenntartójának - a kutatási helyszín biztosításáért, valamint a község alapellátásban dolgozó munkatársainak és a hevesi járóbeteg-szakrendelés labordiagnosztikai egységében dolgozóknak a kutatásban nyújtott közremúködésükért; emellett Prof. Dr. Blázovics Annának, a Semmelweis Egyetem oktatójának a kézirat megírásához nyújtott segítségéért.

\section{Irodalom}

[1] International Diabetes Federation. IDF diabetes atlas. Eighth edition. Brüsszel, 2017. Available from https://www.idf.org/elibrary/epidemiology-research/diabetes-atlas/134-idf-diabetesatlas-8th-edition.html [accessed: July 15, 2018].

[2] Ramlo-Halsted BA, Edelman SV. The natural history of type 2 diabetes. Implications for clinical practice. Prim Care 1999; 26: 771-789.

[3] Giovannucci E, Harlan MD, Archer CM, et al. Diabetes and cancer. A consensus report. Diabetes Care 2010; 33: 1674-1685.

[4] Nakamura J, Kamiya H, Haneda M, et al. Causes of death in Japanese patients with diabetes based on the results of a survey of 45,708 cases during 2001-2010: report of the Committee on Causes of Death in Diabetes Mellitus. J Diabetes Investig. 2017; 8: 397-410.

[5] Jermendy G, Nádas J, Szigethy E, et al. Prevalence rate of diabetes mellitus and impaired fasting glycemia in Hungary: crosssectional study on nationally representative sample of people aged 20-69 years. Croat Med J. 2010; 51: 151-156.

[6] Winkler G, Hidvégi T, Vándorfi Gy, et al. Risk-stratified screening for diabetes mellitus in general practices among adult subjects. [Kockázatalapú diabétesz-szúrés háziorvosi praxisokban, felnőtt egyének körében.] Diabetol Hung. 2011; 19: 111-122. [Hungarian]

[7] Winkler G, Hidvégi T, Vándorfi Gy, et al. Prevalence of undiagnosed abnormal glucose tolerance in adult patients cared for by general practitioners in Hungary. Results of a risk-stratified screening based on FINDRISC questionnaire. Med Sci Monit. 2013; 19: 67-72.

[8] Barkay L, Madácsy L. Risk-stratified screening for diabetes in adolescents: results of the first investigation in Hungary. [Kockázatalapú diabetesszűrés serdülők körében: az első hazai vizsgálat eredményei.] Orv Hetil. 2010; 151: 1742-1747. [Hungarian]

[9] Decree No. 51/1997. (XII. 18.) NM of the minister of welfare on preventive and early diagnostic services that can be utilized in the frame of social health insurance system and on the certification of participation in screening programmes. [51/1997. (XII. 18.) NM rendelet a kötelező egészségbiztosítás keretében igénybe vehető betegségek megelőzését és korai felismerését szolgáló egészségügyi szolgáltatásokról és a szưrővizsgálatok igazolásáról.] Available from: https://net.jogtar.hu/jogszabaly? docid=99700051.NM [accessed: June 12, 2019]. [Hungarian]

[10] American Diabetes Association. Standards of medical care in diabetes 2019. Diabetes Care 2019; 42(Suppl 1): S13-S28.

[11] Vásárhelyi B. Measurement of hemoglobin Alc: analytical principles and their significance in clinical decision making. [Hemo- 
globin-A-lc-szint-mérés: analitikai vonatkozások és ezek jelentősége a klinikai döntéshozatalban.] Orv. Hetil. 2016; 157: 753-757. [Hungarian]

[12] Ivana RS, Sally DP. $\mathrm{HbA}_{\mathrm{lc}}$ as a marker of prediabetes: a reliable screening tool or not? Insights Nutr Metab. 2017; 1: 21-29.

[13] Stiglic G, Fijačko N, Stožer A, et al. Validation of the Finnish Diabetes Risk Score (FINDRISC) questionnaire for undiagnosed type 2 diabetes screening in the Slovenian working population. Diabetes Res Clin Pract. 2016; 120: 194-197.

[14] Jølle A, Midthjell K, Holmen J, et al. Impact of sex and age on the performance of FINDRISC: the HUNT study in Norway. BMJ Open Diabetes Res Care 2016; 4: e000217.

[15] Jermendy Gy, Hidvégi T, Vándorfi Gy, et al. Screening for type 2 diabetes and prediabetes - methodological concerns and feasibility in Hungary. [A 2-es típusú diabetes és elő́llapotainak szürése - módszertani megfontolások, hazai lehetőségek.] Orv Hetil. 2010; 151: 683-690. [Hungarian]

[16] Clinical Practice Guideline - Diagnosis, antihyperglycaemic treatment and care of patients with diabetes in adulthood. [Egészségügyi szakmai irányelv - A diabetes mellitus kórismézéséről, a cukorbetegek antihyperglykaemiás kezeléséről és gondozásáról felnőttkorban.] Emberi Erőforrások Minisztériuma Egészségügyért Felelős Államtitkárság, Egészségügyi Szakmai Kollégium, Budapest. Available from: http://www.diabet.hu/ upload/diabetes/magazine/dh.2017.1.pdf?web_id= [accessed: May 6, 2017]. [Hungarian]

[17] World Health Organization. Global database on body mass index. WHO, Genf. Available from: http://www.assessmentpsychology.com/icbmi.htm [accessed: July 22, 2019].

[18] Zimmet P, Alberti KG, Kaufman F, et al. The metabolic syndrome in children and adolescents - an IDF consensus report. Pediatr Diabetes 2007; 8: 299-306.

[19] International Diabetes Federation. The IDF consensus worldwide definition of the metabolic syndrome. IDF, Brüsszel, 2006. Available from: https://www.idf.org/component/attachments/ attachments.html?id=705\&task=download [accessed: July 27, 2019].

[20] Pénzes J, Tátrai P, Pásztor IZ. Changes in the spatial distribution of the roma population in Hungary during the last decades. [A roma népesség területi megoszlásának változása Magyarországon az elmúlt évtizedekben.] Területi Statisztika 2018; 58: 3-26. DOI: 10.15196/TS580101. Available from: http://www.ksh. hu/docs/hun/xftp/terstat/2018/01/ts580101.pdf [accessed: July 23, 2019]. [Hungarian]

[21] Heves Megyei Önkormányzat Közgyúlése. Information on the health status of the population of Heves county. [Tájékoztató Heves megye lakosságának egészségi állapotáról.] Heves Megyei Kormányhivatal, Népegészségügyi Főosztály, Egészségfejlesztési és Igazgatási Osztály, Eger, 2019. január. Available from: http:// hevesmegye.hu/files/kozgyules/2019/20190125_pub- lic/20190125_01_napirend.pdf [accessed: July 23, 2019]. [Hungarian]

[22] Központi Statisztikai Hivatal. Unemployment rate. [Munkanélküliségi ráta.] KSH, Budapest. Available from: https:// www.ksh.hu/docs/hun/xstadat/xstadat_evkozi/e_qlf027g. html? down $=32$ [accessed: July 23, 2019]. [Hungarian]

[23] Heves Megyei Önkormányzat Közgyúlése. Information on the labor market status in Heves county. [Tájékoztató Heves megye munkaerő-piaci helyzetéről.] Heves Megyei Kormányhivatal, Foglalkoztatási Főosztály, Eger, 2018. november. Available from: http://hevesmegye.hu/files/kozgyules/2018/20181130 _public/20181130_03_napirend.pdf [accessed: July 23, 2019]. [Hungarian]

[24] Magyar Diabetes Társaság (MDT) Háziorvosi Munkacsoportja (ed.: Oláh I). The task of GP-s in the diagnosis of diabetes mellitus, in the antihyperglycaemic treatment and care of the adult patients with diabetes. [A háziorvos feladatai a diabetes mellitus kórismézésében, a cukorbetegek antihyperglykaemiás kezelésében és gondozásában felnőttkorban.] Diabetol Hung. 2017; 25: 79-84. [Hungarian]

[25] Tura A, Göbl C, Moro E, et al. Insulin resistance and beta-cell dysfunction in people with prediabetes according to criteria based on glycemia and glycosylated hemoglobin. Endocr J. 2017; 64: 117-122.

[26] Jagannathan R, Sevick MA, Fink D, et al. The 1-hour post-load glucose level is more effective than $\mathrm{HbA}_{\mathrm{lc}}$ for screening dysglycemia. Acta Diabetol. 2016; 53: 543-550.

[27] Rosella LC, Lebenbaum M, Fitzpatrick T, et al. Prevalence of prediabetes and undiagnosed diabetes in Canada (2007-2011) according to fasting plasma glucose and $\mathrm{HbA}_{\mathrm{lc}}$ screening criteria. Diabetes Care 2015; 38: 1299-1305.

[28] Unwin N, Howitt C, Rose AM, et al. Prevalence and phenotype of diabetes and prediabetes using fasting glucose vs $\mathrm{HbA}_{\mathrm{lc}}$ in a Caribbean population. J Glob Health 2017; 7: 136-146.

[29] Kim CH, Kim HK, Kim EH, et al. Risk of progression to diabetes from prediabetes defined by $\mathrm{HbA}_{\mathrm{lc}}$ or fasting plasma glucose criteria in Koreans. Diabetes Res Clin Pract. 2016; 118: 105111.

[30] World Health Organization. Prevalence of tobacco smoking. WHO, Genf, 2018. Available from: http://apps.who.int/gho/ data/node.sdg. 3 -a-viz!lang=en [accessed: July 24, 2019].

[31] Kovács VA, Erdei G, Bakacs M. Nutrition status of the Hungarian population. [A magyar lakosság tápláltsági állapota.] Országos Gyógyszerészeti és Élelmezés-egészségügyi Intézet, Budapest, 2016. Available from: https://www.ogyei.gov.hu/dynamic/ 3_kovacs_otap\%202014_ea_final.pdf [accessed: July 24, 2019]. [Hungarian]

(Galvács Henrietta, Heves, Semmelweis út 5., 3360 e-mail: galvacshenrietta@gmail.com)

A cikk a Creative Commons Attribution 4.0 International License (https://creativecommons.org/licenses/by/4.0/) feltételei szerint publikált Open Access közlemény, melynek szellemében a cikk bármilyen médiumban szabadon felhasználható, megosztható és újraközölhetö, feltéve, hogy az eredeti szerző és a közlés helye, illetve a CC License linkje és az esetlegesen végrehajtott módositások feltüntetésre kerülnek. (SID_1) 